\title{
Investigating the Indoor Environment Quality Parameters and Their Relationship with Occupants' Satisfaction in Office Buildings: A Review
}

\author{
Masoud Esfandiari ${ }^{1}$, Suzaini Mohamed Zaid ${ }^{2 *}$, Muhammad Azzam Ismail ${ }^{1}$ \\ Centre for Building, Construction \& Tropical Architecture (BuCTA), Faculty of Built Environment, \\ University of Malaya, 50603 Kuala Lumpur, Malaysia \\ *suzaini_zaid@um.edu.my
}

\begin{abstract}
The relation between indoor environmental quality (IEQ) and occupants comfort has become a critical area of research through building life cycle. The importance of the relationship becomes highlighted when IEQ has a strong influence to change people behaviour through its nature specifically in places like an office building where the productivity of occupants remains at the top of everything. In this regard, this manuscript documented the parameters of the indoor environment quality which has a strong influence on occupants' comfort. Through critical review of literature, it has been found that IEQ parameters as thermal, noise, light and air quality could strongly affect the human comfort and health while having a critical role in energy consumption in the building. Moreover, there is a complicated relation among IEQ parameters which make it difficult for a designer to find a balance among them regarding occupants' comfort and productivity and this complication is more confusing in green construction. Many post occupancy evaluation (POE) studies in both conventional and green buildings have carried out, but almost none of them indicated a full satisfaction with IEQ parameters simultaneously. Therefore, this paper investigated among IEQ parameters and their correlation with each other pertaining to occupants' satisfaction, health and productivity in office buildings with different methods of construction.
\end{abstract}

Keywords: Indoor environment quality, occupants' satisfaction, occupants' comfort, occupants' productivity, office building.

\section{INTRODUCTION AND LITERATURE REVIEW}

The common endeavour of human beings across the globe and through the timeline of human is to create a comfortable indoor environment at any circumstance to satisfy people. The overall comfort of indoor environment constantly plays a critical role for human not only because of human comfort but also, it has a critical and major influence on human life (Costanza et al. 2007). Any technical flaw or weakness into the building system regarding the indoor environment condition could bring a sickness or negatively affect human health, or in the worst-case scenario being exposed to this condition for a long-time has a potential to create a fatal or terminal effect on human health. Therefore, the importance of indoor environment quality led numerous designer to try and create standards for it. For instance, ASHREA (2010) guideline, indicated people spend about $80-90 \%$ of their time indoors and many studies highlighted the fact that characteristics of the building have an effect on human health, comfort, satisfaction and wellbeing (Abbaszadeh et al. 2006; Altomonte et al. 2013). Alternatively, The effect of indoor environment passes from just health and satisfaction to occupants productivity in office buildings, as it suggested by a number of researches like Issa et al. (2011); Niemelä et al. (2002)., only a few symptoms of discomfort have a significant consequence on occupants' productivity reduction Moreover, Vischer (2008) believes that indoor environmental quality (IEQ) characters as thermal, visual, acoustic, indoor air quality (IAQ), office layout, etc. physically and psychologically affect human behaviour. As a result, building performance has a critical role for human behaviour and it has become a vast area of research focus for researchers (Al horr et al. 2016).

Regarding building performance, numerous studies indicated that preparing a proper workplace which supports assists and motivates workers by physical and psychological directions is a crucial fact that cannot is neglected from 
building design (Cohen et al. 1986; Hamid et al. 2015). One way to motivate and retain workers is to make them feel included in the organization, and it can be achieved from advantages of the building itself. In the first place to make people feel included companies need to satisfy their worker. To give an example of this fact, Fassoulis et al. (2015) in their research about the relation between workplace satisfaction and productivity in University of Athen's (UOA) found that the administrative staff was not satisfied with their workplace condition; consequently, it reduced their productivity. They also addressed staff's dissatisfaction origins to practical management approach since they were failed to encourage and support a new form of office work for administrative staff (Fassoulis et al. 2015). On the contrary, Wyon (2004) experiment shown that people who are working under a better and improved IEQ have a better work productivity and higher satisfaction in comparison to whom working in the normal indoor environment. Accordingly, it can be achieved that IEQ has a critical role in human health and productivity while it affects their satisfaction by its characters.

\section{METHODOLOGY}

This literature review tried to provide practical information by critically reviewing several academic literatures and achieve a comprehensive analysis of the current literature related to occupants' health, satisfaction and well-being in office buildings. The ultimate objective is to document the state of the art to identifying potential elements which have a fatal influence on occupants' behaviour in office buildings. Therefore, for this study, a range of assorted studies was reviewed to create a key critical and shape the body of the current manuscript. The literature included refereed Journal, conference proceeding, bool, thesis and reported. Three critical stages for this study were hired to shape the body of the manuscript as identifying and collecting, classifying and analyse.

In the first place, the identification of critical keyword was conducted. According to the objective of the study, the following main keyword was employed as indoor environment quality, post-occupancy evaluation, occupants' satisfaction, occupants' well-being and green building. The keywords were searched the databases by main search engines as google scholar, a web of science, science direct, and Wiley to identify and collect related manuscripts. Then, the collected articles were scrutinised to identify which article is more important and related to the study.
The second stage was started after identification of the proper manuscripts to classify them a base of three major criteria as the year of publication, the reputation of journal and article citations.

- Year of Publication: This study tried to cover a wide variety of article ranged from 1980 to 2016. This provided an opportunity to cover the evolution progress of the articles and follow the changes in parameters through the time.

- The reputation of the journal: This played a crucial role to choose superior and highquality manuscripts for the study.

- Highly cited papers: articles were used for this study was divided into two categories base of citation and it has been tried to use high citation ones to maximize the quality of the current research.

The last step of the study was to analyse the founded manuscripts. According to the analysis, the papers were distributed to the categories base on their research and topics to make it easier for further analyses. The created categories were indoor environmental quality, thermal comfort, indoor air quality, light quality, acoustic quality. Therefore, the categories shaped the structure of this research.

\section{INDOOR ENVIRONMENT QUALITY (IEQ)}

Generally, the quality of environment encompasses any building is called Indoor Environment Quality (IEQ). Studies indicated that the interaction between occupants' satisfaction and IEQ is a complex one, therefore occupants' condition has a direct relationship with the quality level of IEQ (Abbaszadeh et al. 2006; Wyon 2004). Figure 1 indicates the importance of developing a suitable and optimal condition for occupants' comfort and satisfaction. It explains that too much light has potential to make very bright workspace and low light causes a $\operatorname{dim}$ workspace which either of them has potential to negatively affect the comfort level of users (Loftness et al. 2005). Therefore, a balance and optimize environment is an essential requirement for high-performing workspace pertain to human productivity. 


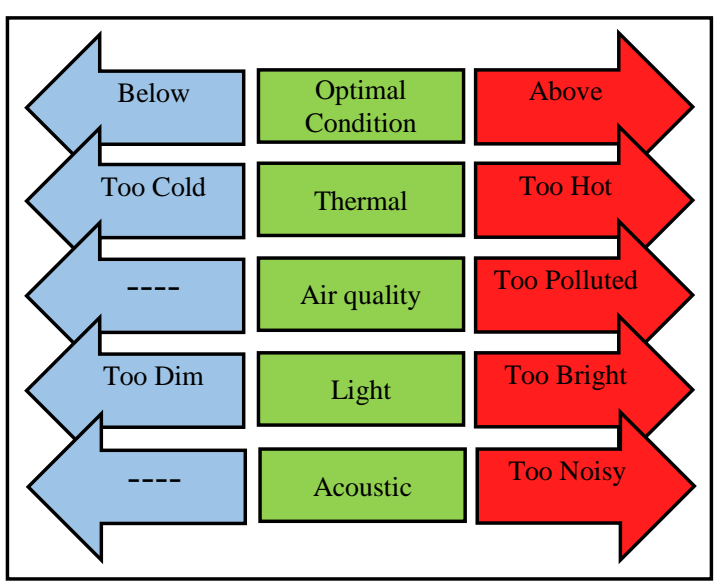

Figure 1 : The effect of not optimising condition on occupants in the indoor environment of buildings.

The influence of IEQ on human behaviour is a complicated relationship which has a lot of variables; however, to achieve a comfort level with the indoor environment a model can be suggested as shown in Figure 2. It indicates that workspace environment affects two distinct aspects of human being as a physical and psychological condition; therefore, IEQ factors can be divided into three categories in relation to how they influence human. The first category includes the parameters which only changes physical condition of the building's host while the second category changes human psychology and the last category includes parameters which have an effect on human physical and psychological together (Vischer 2008).

The range of IEQ parameters can be variable according to the objectives of the study; however, numerous studies specified some parameters as common ones because of their interests and considerable effect on occupants.

Another significant reason for being common of these parameters is related to their shared aspect of energy consumption. These parameters are identified as thermal, acoustic, IAQ, and light quality (Ravindu et al. 2015). These parameters can have a short-term or long-term effect on Human's well-being and health which make their relationship more complex (Fisk et al. 2007). These parameters can have a short-term or longterm effect on Human's well-being and health which make their relationship more complex (Fisk et al. 2007). However, as Vischer (2008) claimed there are other parameters are still existed, which bring changes in human psychology hence, a comprehensive study in green building among its characters needed to be done besides the physical characters to reach a universe study.

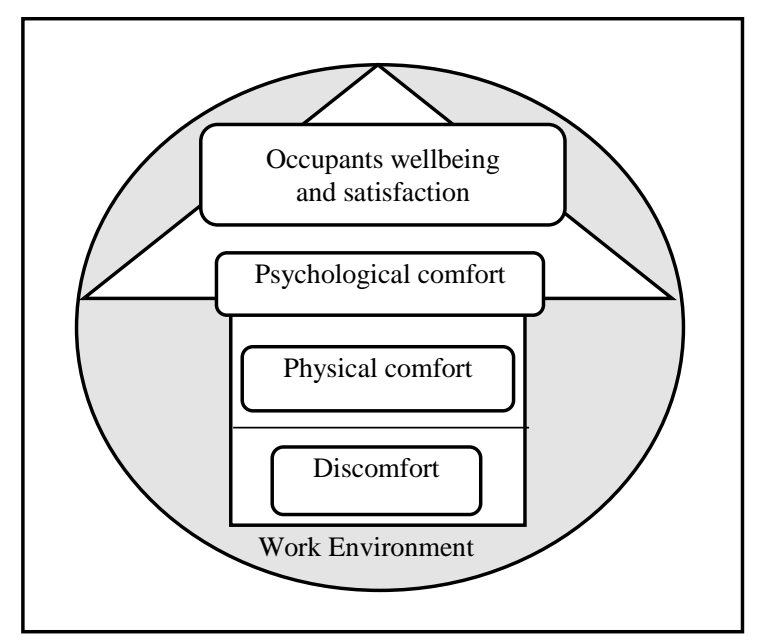

Figure 2 Model of achieving environmental comfort for occupants Adapted from Vischer (2008)

Insufficient indoor environment quality is often manifest in some forms and symptoms of sick building syndromes (SBS) prevail in many office buildings (Bakó-Biró et al. 2004). For instance, significant analyses and discussion on health issue related to the indoor environment were presented by Fisk (2002) indicate that better IEQ resulted in a potential reduction of sick leaving, therefore worker's productivity increment shown its benefit in annual gain in United State. One of the interesting findings of this research explaining that personnel salaries and costs especially those in related to health issues normally surpasses the cost of operating offices, thus investing in strategies to significant return over the long run (Fisk 2002).

\subsection{INDOOR AIR QUALITY (IAQ)}

The term comfort is not commonly used in relation to indoor air quality and it is mainly linked with the lack of discomfort due to odour and sensory irritation (Frontczak et al. 2011). Poor indoor air quality is widely regarded as a significant health, environment and economic problem. Whereas, acceptable air quality is defined as "air in which there are no known contaminants at harmful concentrations as determined by cognizant authorities and with which a substantial majority ( $80 \%$ or more) of the people exposed do not express dissatisfaction" (Ashrae et al. 2007). Thus, the standards which described for providing a better IAQ condition indicated about the minimum percentage of the guest which dissatisfied with air quality. The standards are basically described with the level of 
discomfort caused for indoor spaces occupants. Wyon (2004) claimed that users' performance was reduced when they reported dissatisfaction with IAQ. The reason for the dissatisfaction may refer to building construction details which were hired in the first place to construct the building like paint material, roof covering, building structure, etc. or it could be due to the materials added to office after the construction like office furniture since they might be toxic because of their properties and their chemical nature (Evans 2003). Heating, cooking and indoor activities can also influence indoor air quality. For instance, indoor nitrogen dioxide consecration can be raised more than normal outdoor level by an unwanted gas from kitchen stove (Evans 2003). Indoor air pollutants could have a long-term or short-term effect on occupants', thus they might experience the health issue soon after their exposure to pollutants or years later. The shortterm exposure has immediate possible health issues including dizziness, irritation of the nose or eyes and throat, fatigue, and headaches which they are normally treatable. Sometimes the treatment is simple as identifying and eliminating the source of pollutants which cause the health issue goes away and users find his health in a brief time. Some symptoms of health problems might be aggregated immediately after exposure to some indoor air pollutants. The long-term health issues could show up its symptoms after being under the exposure for a long period time. These effects can be severely fatal and terminal as respiratory diseases, heart disease and cancer (U.S Environmental Protection Agency 2015).

Various variables of pollutants sources inside the building have been identified regarding the parameters which have an influence on occupant health. For instance, Ha (1998) claimed that the primary source of indoor pollutants could be the release gases or particles into the air which cause a poor IAQ. However, main indoor air pollutants variable includes carbon dioxide $\left(\mathrm{CO}_{2}\right)$, odours and other volatile organic compounds (VOC) which are produced by human activities in the building.

Securing a better IAQ requires enough ventilation rate to ensure an acceptable indoor air quality, which depends on the quantity and the nature of the air contaminant and pollutant source in the indoor environment. As Givoni (1969) declared pollution can be removed by the minimum standard for ventilation rate to dilute the contaminant and $\mathrm{CO}_{2}$ concentration with a sufficient supply of oxygen.

\subsection{THERMAL COMFORT}

It is widely accepted that thermal comfort is almost the most important factor of the IEQ and it plays a crucial rule for occupants' comfort and satisfaction. ASHRAE Standard 55 (2013) defined thermal comfort as "that condition of mind that expresses satisfaction with the thermal environment and is assessed by subjective evaluation". Thermal comfort consists of various parameters which classify into two distinct categories as environmental parameters and personal factors. Environmental parameters consist of several parameters such as air temperature, air velocity, air relative humidity and air mean radiant, whereas personal factors consist of human body insulation through clothing and their metabolic rates (Katafygiotou et al. 2015). However, the concept of comfort is various according to multi-type climate zones as well as different types of culture (Nicol et al. 2002). These three factors as physiological adaptation, behavioural adjustment, and psychological habituation or expectation are defining the final thermal adoption per individuals as objectives inside the building (Nikolopoulou et al. 2003).

Comfortable workspace for occupants should be thermally comfortable otherwise it causes dissatisfaction and brings health issue problems (Woo 2010). In this regard, various studies have been tried to create benchmarks and standards for thermal comfort to make it simple for every designer; however, it is hard to put some variables as a common standard for every situation because of the variation of individual's thermal adaptation which is correlated to characteristics such as race, culture, time of year, gender, age, body, psychology and geographic location and climate (Quang et al. 2014). Chun et al. (2008) conducted a Study in climate chambers in Yokohama (Japan) and Seoul (Korea) over the same condition and the results showed that people who were exposed to higher temperatures prior to their time in the climate chamber responded with cooler thermal sensations than people who were first exposed to cooler temperatures. On the other hand, a study on thermal comfort by different gender in residential buildings in Harbin, China showed that females were more sensitive towards temperature changes compared than males; the neutral operative temperature of males was $1.1^{\circ} \mathrm{C}$ lower than that of females (Wang 2006). In support of Wang (2006) another study claimed that women have a lower skin temperature in comparison to men and they are more sensitive to the warmth and less to humidity (Lan et al. 2008). The analysis of this study indicated that women prefer slightly or 
neutral warmer places than men. Therefore, the operative temperature for females should be slightly warmer.

Operative temperature is a temperature sensed by people, ASHRAE Standard 55 (2013) defined it as the "uniform temperature of an imaginary black enclosure in which an occupant would exchange the same amount of heat by radiation plus convection as in the actual non-uniform environment". In another word, it can be described as the average of the ambient air temperatures, mean radiant, weighted by their respective heat transfer coefficients (ASHRAE 2013). The operative temperature is used to evaluate the thermal comfort, however, Schellen et al. (2013) believe that for assessing and evaluating the thermal comfort in the nonuniform thermal environment is not enough to only rely on operative temperature. Therefore, a new methodology was proposed by Jokl (2014) to assess the thermal environment base on operative temperature thermal levels (decitherms, analogous to decibels in acoustics).

On the other hand, the effective temperature (ET) is the other important environment indices which are defined by ASHRAE (2013) as "The effective temperature is the temperature at $50 \%$ $\mathrm{RH}$ that yields the same total heat loss from the skin as for the actual environment". To make it simple, the equivalent temperature of an environment corresponds to the same temperature there would be in an environment where the temperature is uniform, the air is stationary and the moisture content corresponds to $100 \%$, and therefore, the human body cannot exchange energy with the environment. For instance, there is a relation between human thermal comfort and the concept of the ET in the air-conditioning system design, which combines the humidity and temperature into single indices, therefore, two environments with same ET evoke the same thermal response, while they have different humidity and temperatures, but the air velocity must be the same. (ASHRAE, 2013). The ET represents the thermal comfort level for human in perspective of designing the indoor thermal environment. It should be considered that many other factors have an influence on thermal comfort specifically the air velocity. However, the effect of air velocity has relation with humidity and to provide the thermal comfort for a human it is common to reduce the humidity when an increase in indoor temperature happens.

Varied variables of thermal comfort make it more complicated to prepare a comfortable condition regarding thermal comfort for occupants, as a result, despite all the professional endeavour to craft benchmarks for thermal comfort, it is still one of the most dissatisfaction sources in the office buildings (Federspiel et al. 1998). Moreover, Jamaludin (2011) found that by applying natural ventilation and courtyard it is possible to reduce the energy consumption. Therefore, one reason for dissatisfaction beside the above matters can be related to the energy consumption of the buildings, which there is a tempting to change the thermal comfort to a nonoptimal level just to save energy (Catalina et al. 2012).

\subsection{ACOUSTIC COMFORT}

Navai et al. (2003) defined acoustic comfort as "a state of contentment with acoustic conditions". Therefore, any sound could be considered as noise by occupants when it starts to push the human toleration. In other words, inappropriate acoustic inside the office building could cause occupants to lose their concentrate on their work. Moreover, the quality of the sound environment has some parameters as physical properties of a room and physical properties of sound itself. The sound has two characters as sound pressure level (short-term and long-term period) and sound frequency. The acoustic quality is affected by reverberation time, absorption, sound insulation and physical room properties (Cowan 2007).

In relation to sound pressure level, Mui et al. (2006) claimed that the neutral sound pressure level for occupants to feel comfortable in a typical air-conditioned room should have mean of $57.5 \mathrm{~dB}$, minimum of $45 \mathrm{~dB}$ and the maximum of $70 \mathrm{~dB}$. Another study found that occupants had a satisfaction with sound pressure level when the noise level was below $49.6 \mathrm{~dB}$, and when the noise level passed this threshold the subjects had started to feel unsatisfactory (Huang et al. 2012).

Another major parameter is reverberation, it is a phenomenon happens when the reflection of all the surfaces inside a room combine to each other and produce the reverberation. It can influence and reduce the speech intelligibility and increase the sound level in a room (Rossing 2007). One way to reduce or eliminate the reverberation is to absorb the unwanted reflection off surfaces (Rossing 2007). Echoes elimination is also possible by absorption. For instance, the rear wall of the auditorium is one the prime candidates for implementing the absorptive material, since the rear walls have great potential to create the echoes and cause the ultimate dissatisfaction or discomfort for the audiences. 
Therefore, the users' discomfort has a relation to sufficient acoustic quality in the indoor environment. the sources of discomfort should be eliminated to prevent the discomfort and prepare a comfortable environment regarding noise. Privacy and distractions are the main characters of the acoustic discomfort in an office building (Banbury et al. 2005). Studies tried to find the relation between these two parameters to users' productivity, for instance, Huang et al. (2012) claimed that the productivity of occupants in an office has a direct relation with privacy and distraction.

The spaces which the speech causes a prevailing source of the noise, a concern regarding privacy might occur. One of a good example of this scenario is the office environment which always creates privacy concerns and how they are needed to be handled. Danielsson (2005) claimed that the privacy issue is more severe and dissatisfied in the open plan office with a high number of users than the cellular and individual offices. Open plan offices are famous for their major problem with noise, some cross-sectional office surveys that have compared different office layouts, have shown that the most severe factor causing office dissatisfaction is noise (Becker et al. 1983).

Noise in the building is created by various inside and outside sources like peoples talking, mechanical, electrical, and outsiders sounds. The most common noise sources in buildings, other than the inhabitants, are related to heating, ventilating, air conditioning (HVAC) systems, plumbing systems, and electrical systems (Cowan 2007). The acoustic environment is influenced by such physical room properties as sound insulation, absorption and reverberation time (Cowan 2007). Considering the acoustic quality in offices is an unavoidable fact for increasing work productivity as it was mentioned in different studies (Pejtersen et al. 2006). Therefore, offices should be designed in the way that totally satisfied occupants in the related of acoustic quality.

\subsection{INDOOR ENVIRONMENT LIGHT QUALITY}

Light is one of the essential element needed for human populations and it is known to correlate in affecting their physical and psychological behaviours. A good lighting is not only able to provide a basic required level for visual performance, but it also determines spatial appearance, provides safety and indirectly contributes to occupants well-being (Rea 2000).
Recent studies aimed to find a correlation between the quality of indoor environment light and human performance. The result of this studies indicated that being exposed to insufficient or inappropriate light has the ability to disrupt human standard rhythms, therefore it might have adverse results for human performance, safety and health (Burgess et al. 2002). For instance some studies investigated the relation of light quality to human behaviour and the result indicated that a decrease in the amount of flicker in light, i.e., the magnitude of the rapid cyclic change in illuminance over time, may be associated with a decrease in a headache and eye strain which resulted in an increase over worker performance (Wilkins et al. 1989). Therefore, lighting environment can influence an occupant's safety, the level of fatigue, comfort, as well as work efficiency and accuracy (Hwang et al. 2010).

Providing a high quality lighting system is an essential factor in the office building to ensure the visibility of the objects, occupants' health, and comfort; however, the quality of the light significantly depends on several aspects of the lighting system as luminance, illuminance (intensity of light that impinges upon a surface), avoiding the glare, uniformity, distribution, and colour contrast (Rea 2000). Regarding illuminance the recommended range significantly depends on the need for visual activity and the age of the user, whereas for the maximum luminance ratio guidelines come with some recommendation, i.e., the range of luminance in the visual field (Veitch et al. 2000).

Indoor environment light is normally provided by the different source of light as daylight, artificial lighting, and the combination of them which choosing an appropriate system depends on the design factors of the building. Daylight system is an innovative approach which earned a lot of attention after the introduction of sustainability, indeed the source of the daylight is the sun. The indoor daylighting is affected by two major factors as the characteristics of the building and the total natural light from the sky. Building characters include windows, building shading, indoor partitions, direction of the building, atrium, and skylights (Fontoynont et al. 2004). The amount and direction of natural light are varied due to movement of the sun and the condition of the sky (Dean 2005). Regarding the artificial light, the indoor light quality relies on the several aspects of lighting function as a number of luminaires, locations, and light source type as well as the specifics of the indoor surfaces materials like their colour and spectral 
reflectivity. Moreover, the details of controlling the indoor lighting system as a, no control over lights, manual control of overhead, automatic dimming of artificial light, and task lighting has a strong potential to influence lighting quality.

\subsection{GREEN CONSTRUCTION}

Green building or Green construction has brought massive alternation to building construction after it was introduced to the global community. It's quick and long-lasting benefits are no longer hidden to researchers and industrials, as a result; numerous varieties of businesses have concentrated on going green to construct and operate buildings in an environmentally responsible manner (Robinson et al. 2012). The increasing public demand for green construction is not only because of environmentally concern of customers but also because of its associated benefits with sustainable materials and energy efficiency (Robinson et al. 2012). To evaluate the green aspects of buildings United Kingdom pioneered and established the first green building rating system as "Building Research Establishment Environmental Assessment Method" (BREEAM) in 1990. The United States then established its own rating system eight years after in 1998, known as "Leadership in Energy and Environmental Design" (LEED). More countries have conducted the rating system in the following years as Australia (Green Star) in 2003 and Singapore (Green Mark) in 2005.

Green construction has been hiring new design methods for achieving greenery goals specifically regarding saving the energy like employing natural ventilation, atrium and daylight or using local and sustainable materials (Aflaki et al. 2015; Moosavi et al. 2014). Despite the benefits of this methods they also have some flaw for instance by hiring daylight for users it might increase the temperature and influence occupants feeling about thermal comfort through absorbing more solar radiation. These new methods have changed old rules for IEQ and its parameters, therefore, studies have started to investigate and compare the relation of green building's IEQ with occupants satisfaction (Newsham et al. 2013). As result of this shifting to green construction, a new approach in research earned lots of attention to compromise whether green building outperforms to the non-green building, especially in industrial and commercial building. In this concept US Green Building Council (2016) claims that green building has better performance than non-green building, hence; numerous researchers have started to identify this aspect of green building (Liang et al. 2014).

\subsection{BUILDING PERFORMANCE EVALUATION (BPE)}

One way to identify the performance of the building and the effect of IEQ on occupants' satisfaction and wellbeing is post-occupancy evaluation (POE) which is a platform for the systematic study of buildings once occupied. According to Zimring et al. (1980), POE is an effective examination for human users of occupied design environments while Ilesanmi (2010) states that POE is about procedures for determining whether or not design decisions made by the architect are delivering the performance needed by those who are using the building and using occupants as a benchmark in evaluation. In this regard, assorted studies tried to evaluate building performance by POE and come up with a solution for next generation of building design. Therefore, the assessment process of a building has upgraded form POE to Building Performance Evaluation (BPE) with more attention to occupants' view of the building. In this term, Mallory-Hill et al. (2012) claim that the $\mathrm{BPE}$ is a comprehensive process which is encompassing some rigorous and deep activities, including research, analyses, comparison, evaluation and feedback from both occupants and environments. As a result, BPE takes a place from construction, planning, occupancy to recycling, in another word the whole building lifecycle (Mallory-Hill et al. 2012). Indeed, BPE shows its value to designers when it comes with access to the comprehensively updated database of information, which is gathered from precise evaluation research in relation to the specific type of building, hence, they will be able to eliminate the nuisance factors from design to creating better building (Fowler et al. 2011).

\section{DISCUSSION}

It is possible to divide buildings into two categories based on the methods of construction as green or non-green construction regarding occupants' satisfaction and well-being from IEQ. Various studies have tried to compare and report the performance of the building in these two categories from the perspective of occupants. It is clear that the results are different from one building to another; therefore there is a complication for reaching a consensus among all buildings in each category. In this regard, some of the studies claimed that the occupants of green buildings reported a better satisfaction and 
healthier rather than non-green buildings, but in contrast, some studies indicated that there is no significant difference between the users' satisfaction and well-being from IEQ in green and non-green buildings. For instance, MacNaughton et al. (2016) by hiring POE compared occupants satisfaction, which they moved from conventional building to green building and result showed that the participants in green buildings reported more satisfaction in compare of conventional one from IEQ.

This indicated that green strategy has a better outcome for occupants, however, it is not possible to generalize this finding for every green building as Paul et al. (2008) did a research to compare occupants satisfaction from green and non-green building and the results indicated that there is no huge difference in occupants satisfaction with IEQ from green and non-green buildings. Moreover, Leaman et al. (2007) claimed that it is common to find $30-40 \%$, dissatisfied occupants. Therefore, it is important to do more compression and investigation through these methods of construction and replace them with a better solution to reduce the dissatisfaction. Table 26 shows some of the compression studies which investigated the occupants' satisfaction in green buildings and non-green buildings.
Even though more studies indicated occupants from green buildings are more satisfied from IEQ rather than non-green ones, but it is not possible to accept it as fact and generalize it to all building. The only difference might be related to the sequence of the more satisfied parameters of IEQ in both buildings type. A number of the studies even claimed that some of the IEQ parameters in conventional buildings are performing better than the green ones. For instance, Leaman et al. (2007) investigated occupants satisfaction form IEQ among 177 green and non-green buildings, the founding of the study indicated that although users are more satisfied with overall IEQ of green building, but for parameters like temperature people voted for less satisfied in summer time with green buildings, or for the other parameter as light quality people reported less glare from the artificial lights but more glare with sky and sunlight in comparison with conventional buildings. The reason for this report of light might be related to the greenery goal of construction to use the daylight and save energy, however by applying such a method for daylight usage an increase of glare dissatisfaction from sky and sunlight happened which shifted the dissatisfaction from artificial light to daylight

Table 1 occupants' respond for IEQ condition from green and non-green building.

\begin{tabular}{|c|c|c|c|c|}
\hline Authors & Article title & Building types & $\begin{array}{c}\text { Evaluation } \\
\text { methodology }\end{array}$ & Results \\
\hline $\begin{array}{l}\text { (MacNaugh } \\
\text { ton et al. } \\
\text { 2016) }\end{array}$ & $\begin{array}{l}\text { Environmental } \\
\text { perceptions and } \\
\text { health before and } \\
\text { after relocation to a } \\
\text { green building }\end{array}$ & $\begin{array}{l}\text { Conventional } \\
\text { and Green }\end{array}$ & $\begin{array}{l}\text { Questionnaire survey, } \\
\text { Over } 30 \text { participants, } \\
\text { first occupants surveyed } \\
\text { in the conventional } \\
\text { building then they had } \\
\text { been moved to green } \\
\text { building for } \\
\text { compression. }\end{array}$ & $\begin{array}{l}\text { Participants in green buildings reported } \\
\text { more satisfaction in compare of } \\
\text { conventional one from IEQ (Light, noise, } \\
\text { air quality, thermal) and fewer symptoms. }\end{array}$ \\
\hline $\begin{array}{l}\text { (Ravindu et } \\
\text { al. 2015) }\end{array}$ & $\begin{array}{l}\text { Indoor } \\
\text { environment } \\
\text { quality of green } \\
\text { buildings: Case } \\
\text { study of a LEED } \\
\text { platinum certified } \\
\text { factory in a warm } \\
\text { humid tropical } \\
\text { climate }\end{array}$ & $\begin{array}{l}\text { Green, } \\
\text { Conventional }\end{array}$ & $\begin{array}{l}\text { Questionnaire survey, } \\
\text { compression of } \\
\text { Factories }\end{array}$ & $\begin{array}{l}\text { Thermal comfort, ventilation, and ability } \\
\text { to control indoor environment of the } \\
\text { green factory were comparatively less } \\
\text { satisfactory. } \\
\text { Ratings for acoustics, indoor air quality } \\
\text { and work layout were not significantly } \\
\text { different between the two factories. } \\
\text { The other five factors, namely, views to } \\
\text { outside, lighting, cleanliness, furniture, } \\
\text { and privacy had significantly higher } \\
\text { satisfaction ratings for the green factory. }\end{array}$ \\
\hline $\begin{array}{l}\text { (Liang et al. } \\
\text { 2014) }\end{array}$ & $\begin{array}{l}\text { Satisfaction of } \\
\text { occupants toward } \\
\text { indoor } \\
\text { environment } \\
\text { quality of certified } \\
\text { green office } \\
\text { buildings in } \\
\text { Taiwan }\end{array}$ & $\begin{array}{l}\text { Green, } \\
\text { Conventional }\end{array}$ & $\begin{array}{l}\text { Questionnaire survey, } \\
\text { Field measurement }\end{array}$ & $\begin{array}{l}\text { Responded reported better comfortable } \\
\text { and satisfied with IEQ (Acoustic, Visual, } \\
\text { Thermal, Air) of green building in } \\
\text { comparison with conventional one. } \\
\text { Among the IEQ factor of green building } \\
\text { Acoustic quality is earned the most } \\
\text { comfortable item. In the meantime, air } \\
\text { quality reported as the most }\end{array}$ \\
\hline
\end{tabular}




\begin{tabular}{|c|c|c|c|}
\hline & & & uncomfortable item. \\
\hline $\begin{array}{l}\text { (Paul et al. } \\
\text { 2008) }\end{array}$ & $\begin{array}{l}\text { A comparison of } \\
\text { occupant comfort } \\
\text { and satisfaction } 1 \text { Green \& } 2 \\
\text { between a green } \\
\text { conventional, } \\
\text { building and a } \begin{array}{l}\text { university } \\
\text { buildings } \\
\text { conventional } \\
\text { building }\end{array}\end{array}$ & IEQ Survey, POE, & $\begin{array}{l}\text { The overall occupants' response to IEQ } \\
\text { survey was similar between two building } \\
\text { and there was not any significant } \\
\text { difference between the two type buildings } \\
\text { performance. }\end{array}$ \\
\hline
\end{tabular}

However, there could be a conflict between occupants' satisfaction and building performance specifically for green buildings. For instance, thermal comfort inside the building has a direct effect on energy efficiency, it means for providing a more comfortable thermal condition, there is need to use more energy to maintain the temperature, air velocity or humidity which has a conflict with energy efficiency (Koponen et al. 2001). Moreover, among the IEQ parameters, a confliction might happen as well. For instance, by applying natural ventilation the air velocity will be increased or even high ventilation rate for better IAQ could increase the background noise which it might have an adverse influence on the acoustic comfort of occupants (Pellerin et al. 2003). In relation to applying the daylight the same conflict might happen, Mahdavi et al. (2015) believe that using the shading system to control the heat gain by solar in east and west orientation causes the excessive reduction of daylight inside the building.

Table 27 shows some studies which investigated the building performance in the view of occupants. It can be deduced that there is no consensus among studies for the rank among the IEQ parameters. The reason might be related to the goals of the designer or it can be related to the confliction among parameters. Another example of this confliction might be found in the study of (Liang et al. 2014), since the users reported more satisfaction with light quality where the thermal comfort got less satisfaction so the reason might be related to the greenery construction goals which provided daylight for users and more daylight inside the building could influence the thermal comfort by making inside the building warmer. Another example can be found the research of Ravindu et al. (2015) the occupants reported acoustic quality as the most satisfied parameters and indoor air quality and thermal comfort earned less satisfaction respectively. One reason for this sequence might be related to the confliction between providing acoustic quality by reducing the inside noises such as a mechanical system for thermal comfort or dropping the air velocity rate. In contrast to this study, Abbaszadeh et al. (2006) found that occupants reported indoor air quality as the most satisfied character and acoustic quality as the less satisfied one.

Table 2 POE studies which investigated IEQ in the view of occupants

\begin{tabular}{|c|c|c|c|c|c|c|c|}
\hline \multirow{2}{*}{ Authors } & \multirow{2}{*}{ Article title } & \multicolumn{2}{|c|}{$\begin{array}{l}\text { Building } \\
\text { types }\end{array}$} & \multicolumn{4}{|c|}{ IEQ rank } \\
\hline & & Green & $\begin{array}{l}\text { Non- } \\
\text { green }\end{array}$ & 1 & 2 & 3 & 4 \\
\hline $\begin{array}{l}\text { Amasyali et } \\
\text { al. (2016) }\end{array}$ & $\begin{array}{l}\text { Energy-related values and satisfaction levels of } \\
\text { residential and office building occupants }\end{array}$ & - & $\sqrt{ }$ & LQ & IAQ & $\mathrm{TC}$ & - \\
\hline $\begin{array}{l}\text { Pei et al. } \\
(2015)\end{array}$ & $\begin{array}{l}\text { Comparative study on the indoor environment } \\
\text { quality of green office buildings in China with } \\
\text { a long-term field measurement and } \\
\text { investigation }\end{array}$ & $\sqrt{ }$ & - & LQ & $\mathrm{TC}$ & IAQ & AQ \\
\hline $\begin{array}{l}\text { Ravindu et } \\
\text { al. (2015) }\end{array}$ & $\begin{array}{l}\text { Indoor environment quality of green buildings: } \\
\text { Case study of an LEED platinum certified } \\
\text { factory in a warm humid tropical climate }\end{array}$ & $\sqrt{ }$ & - & AQ & LQ & $\mathrm{TC}$ & IAQ \\
\hline (Liang et al. & Satisfaction of occupants toward indoor & $\sqrt{ }$ & - & LQ & $\mathrm{AQ}$ & IAQ & $\mathrm{TC}$ \\
\hline
\end{tabular}




\begin{tabular}{llllllllll}
\hline 2014) & $\begin{array}{l}\text { environment quality of certified green office } \\
\text { buildings in Taiwan }\end{array}$ & & & & & & \\
\hline Woo (2014) & $\begin{array}{l}\text { A systematic post-occupancy evaluation in } \\
\text { green-rated high-rise office buildings }\end{array}$ & $\sqrt{ }$ & - & TC & AQ & LQ & IAQ \\
\hline $\begin{array}{l}\text { Frontczak } \\
\text { et al. (2012) }\end{array}$ & $\begin{array}{l}\text { Quantitative relationships between occupant } \\
\text { satisfaction and satisfaction aspects of indoor } \\
\text { environmental quality and building design }\end{array}$ & - & $\sqrt{ }$ & TC & AQ & LQ & IAQ \\
\hline $\begin{array}{l}\text { Wong et al. } \\
\text { (2008) }\end{array}$ & $\begin{array}{l}\text { A multivariate-logistic model for acceptance of } \\
\text { indoor environmental quality (IEQ) in offices }\end{array}$ & - & $\sqrt{ }$ & LQ & AQ & TC & IAQ \\
\hline $\begin{array}{l}\text { Abbaszadeh } \\
\text { et al. (2006) }\end{array}$ & $\begin{array}{l}\text { Occupant satisfaction with indoor } \\
\text { environmental quality in green buildings }\end{array}$ & $\sqrt{ }$ & - & IAQ & LQ & TC & AQ \\
\hline $\begin{array}{l}* \text { Thermal Comfort=TC, Light Quality=LQ, Acoustic Quality=AQ, Indoor Air Quality=IAQ } \\
* * \text { IEQ rank is based on the satisfaction mean of occupants' responds for the IEQ parameters. }\end{array}$ & & \\
\hline
\end{tabular}

\section{CONCLUSIONS}

This paper tried to document the ways that occupants' satisfaction is affected by indoor environmental parameters. The literature review highlighted the fact that IEQ has several parameters as thermal comfort, light quality, acoustic quality, IAQ, office layout, etc. Each of these parameters have their own characters which have an influence on users' satisfaction and even a small flaw in the design of these parameters bring dissatisfaction for users. However, the green buildings require a pioneering design to produce a balance between IEQ parameters with energy saving and occupants' satisfaction and well-being. As it was mentioned the confliction among parameters could cause a challenge for designer and following that a monitoring system is essential to ensure that buildings are delivering the performance which they are designed for. In this regard, designers should consider a spectrum of IEQ parameters as thermal, light, acoustic, IAQ, office layout, etc. if they are seeking to deliver a high-performance building.

\section{ACKNOWLEDGEMENT}

This research is supported by University Malaya Research Fund Assistance (BKP) scheme (BK061-2015).

\section{REFERENCES}

Abbaszadeh, S., Zagreus, L., Lehrer, D., \& Huizenga, C. (2006). Occupant satisfaction with indoor environmental quality in green buildings. Proceedings of Healthy Buildings. Lisbon , 3, 365-370.

Aflaki, A., Mahyuddin, N., Mahmoud, Z. A.-C., \& Baharum, M. R. (2015). A review on natural ventilation applications through building façade components and ventilation openings in tropical climates. Energy and Buildings, 101, 153-162.
Al horr, Y., Arif, M., Katafygiotou, M., Mazroei, A., Kaushik, A., \& Elsarrag, E. (2016). Impact of indoor environmental quality on occupant well-being and comfort: A review of the literature. International Journal of Sustainable Built Environment, $5(1)$,

$1-11$.

doi:http://dx.doi.org/10.1016/j.ijsbe.2016.03.0 06

Altomonte, S., \& Schiavon, S. (2013). Occupant satisfaction in LEED and non-LEED certified buildings. Building and Environment, 68, 6676. doi:10.1016/j.buildenv.2013.06.008

Amasyali, K., \& El-Gohary, N. M. (2016). Energy-related values and satisfaction levels of residential and office building occupants. Building and Environment, 95, 251-263. doi:10.1016/j.buildenv.2015.08.005

ASHRAE. (2013). Handbook Fundamentals. Inc.: Atlanta, GA, USA: American society of heating, refrigerating and air-conditioning engineers.

Ashrae, A., \& Standard, A. (2007). 62.1. 2007, Ventilation for Acceptable Indoor Air Quality. American Society of Heating, Refrigerating and Air-Conditioning Engineers, Inc., Atlanta, GA.

ASHRAE Standard 55. (2013). Standard 552004-Thermal Environmental Conditions for Human Occupancy ASHRAE Inc., Atlanta, GA.

ASHREA. (2010). Interactions Affecting the Achievement of Acceptable Indoor Environments.

Bakó-Biró, Z., Wargocki, P., Weschler, C. J., \& Fanger, P. O. (2004). Effects of pollution from personal computers on perceived air quality, SBS symptoms and productivity in offices. Indoor Air, 14(3), 178-187. doi:10.1111/j.1600-0668.2004.00218.x

Banbury, S., \& Berry, D. (2005). Office noise and employee concentration: Identifying causes of disruption and potential improvements. Ergonomics, 48(1), 25-37. 
Becker, F. D., Gield, B., Gaylin, K., \& Sayer, S. (1983). Office Design in a Community College: Effect on Work and Communication Patterns. Environment and Behavior, 15(6), 699-726. doi:10.1177/0013916583156002

Burgess, H. J., Sharkey, K. M., \& Eastman, C. I. (2002). Bright light, dark and melatonin can promote circadian adaptation in night shift workers. Sleep Medicine Reviews, 6(5), 407 420.

Catalina, T., \& Iordache, V. (2012). IEQ assessment on schools in the design stage. Building and Environment, 49, 129-140. doi:http://dx.doi.org/10.1016/j.buildenv.2011. 09.014

Chun, C., Kwok, A., Mitamura, T., Miwa, N., \& Tamura, A. (2008). Thermal diary: Connecting temperature history to indoor comfort. Building and Environment, 43(5), 877-885.

doi:https://doi.org/10.1016/j.buildenv.2007.01 .031

Cohen, S., Evans, G. W., Stokols, D., \& Krantz, D. S. (1986). Stress Processes and the Costs of Coping Behavior, Health, and Environmental Stress (pp. 1-23). Boston, MA: Springer US.

Costanza, R., Fisher, B., Ali, S., Beer, C., Bond, L., Boumans, R., . . . Snapp, R. (2007). Quality of life: An approach integrating opportunities, human needs, and subjective well-being. Ecological Economics, 61(2-3), 267-276.

doi:http://dx.doi.org/10.1016/j.ecolecon.2006. 02.023

Cowan, J. (2007). Building Acoustics. In T. D. Rossing (Ed.), Springer Handbook of Acoustics (pp. 387-425).

Danielsson, C. (2005). Office environment, health and job satisfaction: an explorative study of office design's influence.

Dean, E. T. (2005). Daylighting design in libraries. California: U.S. Institute of Museum and Library Services.

Evans, G. W. (2003). The built environment and mental health. Journal of Urban Health, 80(4), 536-555.

Fassoulis, K., \& Alexopoulos, N. (2015). The workplace as a factor of job satisfaction and productivity: A case study of administrative personnel at the University of Athens. Journal of Facilities Management, 13(4), 332-349. doi:doi:10.1108/JFM-06-2014-0018

Federspiel, C. C., Bridges, B., \& Langkilde, G. (1998). Statistical analysis of unsolicited thermal sensation complaints in commercial buildings/Discussion. ASHRAE Transactions, $104,912$.
Fisk, W. J. (2002). How IEQ affects health, productivity. ASHRAE journal, 44(5), 56.

Fisk, W. J., Lei-Gomez, Q., \& Mendell, M. J. (2007). Meta-analyses of the associations of respiratory health effects with dampness and mold in homes. Indoor Air, 17(4), 284-296. doi:10.1111/j.1600-0668.2007.00475.x

Fontoynont, M., Tsangrassoulis, A., \& Synnefa, A. (2004). SynthLight handbook. France: European Commission.

Fowler, K., Rauch, E., Henderson, J., \& Kora, A. (2011). Re-assessing green building performance: A post occupancy evaluation of 22 GSA buildings. Pacific Northwest National Laboratory: Richland, WA, USA.

Frontczak, M., Schiavon, S., Goins, J., Arens, E. A., Zhang, H. P. D., \& Wargocki, P. (2012). Quantitative relationships between occupant satisfaction and satisfaction aspects of indoor environmental quality and building design. Indoor Air Journal, 22(2), 119-122. doi:10.1111/j.1600-0668.2011.00745.x

Frontczak, M., \& Wargocki, P. (2011). Literature survey on how different factors influence human comfort in indoor environments. Building and Environment, 46(4), 922-937. doi:http://dx.doi.org/10.1016/j.buildenv.2010. 10.021

Givoni, B. (1969). Man, climate and architecture. Elsevier;().

Ha, M. M. (1998). Indoor air quality: Office health, safety and well-being. (MQ42314 M.E.Des.), University of Calgary (Canada), Ann Arbor. ABI/INFORM Complete database.

Hamid, N. Z. A., \& Hassan, N. (2015). The Relationship Between Workplace Environment and Job Performance in Selected Government Offices in Shah Alam, Selangor. International review of management and business research, 4(3), 845-851.

Huang, L., Zhu, Y., Ouyang, Q., \& Cao, B. (2012). A study on the effects of thermal, luminous, and acoustic environments on indoor environmental comfort in offices. Building and Environment, 49, 304-309. doi:http://dx.doi.org/10.1016/j.buildenv.2011. 07.022

Hwang, T., \& Kim, J. T. (2010). Effects of indoor lighting on occupants' visual comfort and eye health in a green building. Indoor and Built Environment, 1420326X10392017.

Ilesanmi, O. A. (2010). Post-occupancy evaluation and residents' satisfaction with public housing in Lagos, Nigeria. Journal of Building Appraisal, 6(2), 153-169. doi:10.1057/jba.2010.20 
Issa, M., Rankin, J., Attalla, M., \& Christian, A. (2011). Absenteeism, performance and occupant satisfaction with the indoor environment of green Toronto schools. Indoor and Built Environment, 20(5), 511-523.

Jamaludin, A. A. (2011). Energy performance of three residential college buildings in University of Malaya campus, Kuala Lumpur. Journal of Design and Built Environment, 9(1).

Jokl, M. V. (2014). A methodology for the comprehensive evaluation of the indoor climate based on human body response: Evaluation of the hygrothermal microclimate based on human psychology. Energy and Buildings, 85(Supplement C), 458-463. doi:https://doi.org/10.1016/j.enbuild.2014.09. 061

Katafygiotou, M., \& Serghides, D. (2015). Bioclimatic chart analysis in three climate zones in Cyprus. Indoor and Built Environment, 24(6), 746-760.

Koponen, K. I., Asmi, A., Keronen, P., Puhto, K., \& Kulmala, M. (2001). Indoor air measurement campaign in Helsinki, Finland 1999 - the effect of outdoor air pollution on indoor air. Atmospheric Environment, 35(8), 1465-1477.

doi:http://dx.doi.org/10.1016/S13522310(00)00338-1

Lan, L., Lian, Z., Liu, W., \& Liu, Y. (2008). Investigation of gender difference in thermal comfort for Chinese people. European Journal of Applied Physiology, 102(4), 471-480. doi:https://doi.org/10.1007/s00421-007-06092

Leaman, A., \& Bordass, B. (2007). Are users more tolerant of 'green' buildings? Building Research \& Information, 35(6), 662-673. doi:10.1080/09613210701529518

Liang, H. H., Chen, C.-P., Hwang, R.-L., Shih, W.-M., Lo, S.-C., \& Liao, H.-Y. (2014). Satisfaction of occupants toward indoor environment quality of certified green office buildings in Taiwan. Building and Environment, $\quad 72, \quad 232-242$ doi:http://dx.doi.org/10.1016/j.buildenv.2013. 11.007

Loftness, V., Hartkopf, V., Gurtekin, B., Hua, Y., Qu, M., Snyder, M., \& Gu, Y. (2005). Building Investment Decision Support (BIDSTM). Retrieved from Carnegie Mellon University:

MacNaughton, P., Spengler, J., Vallarino, J., Santanam, S., Satish, U., \& Allen, J. (2016). Environmental perceptions and health before and after relocation to a green building.
Building and Environment, 104, 138-144. doi:10.1016/j.buildenv.2016.05.011

Mahdavi, A., Inangda, N., \& Rao, S. (2015). Impacts of orientation on daylighting in highrise office buildings in Malaysia. Journal of Design and Built Environment, 15(2).

Mallory-Hill, S., Preiser, W. F., \& Watson, C. G. (2012). Enhancing building performance: John Wiley \& Sons.

Moosavi, L., Mahyuddin, N., Ab Ghafar, N., \& Azzam Ismail, M. (2014). Thermal performance of atria: An overview of natural ventilation effective designs. Renewable and Sustainable Energy Reviews, 34, 654-670. doi:http://dx.doi.org/10.1016/j.rser.2014.02.0 35

Mui, K. W., \& Wong, L. T. (2006). A method of assessing the acceptability of noise levels in air-conditioned offices. Building Services Engineering Research and Technology, 27(3), 249-254. doi:10.1191/0143624406bse157tn

Navai, M., \& Veitch, J. A. (2003). Acoustic Satisfaction in Open-Plan Offices: Review and Recommendations. Retrieved from

Newsham, G. R., Birt, B. J., Arsenault, C., Thompson, A. J. L., Veitch, J. A., Mancini, S., . . . Burns, G. J. (2013). Do "green' buildings have better indoor environments? New evidence. Building Research and Information, 41(4), 415-434. doi:10.1080/09613218.2013.789951

Nicol, J. F., \& Humphreys, M. A. (2002). Adaptive thermal comfort and sustainable thermal standards for buildings. Energy and Buildings, 34(6), 563-572. doi:https://doi.org/10.1016/S03787788(02)00006-3

Niemelä, R., Rautio, S., Hannula, M., \& Reijula, K. (2002). Work environment effects on labor productivity: an intervention study in a storage building. American journal of industrial medicine, 42(4), 328-335. doi:10.1002/ajim.10119

Nikolopoulou, M., \& Steemers, K. (2003). Thermal comfort and psychological adaptation as a guide for designing urban spaces. Energy and Buildings, 35(1), 95-101. doi:http://dx.doi.org/10.1016/S03787788(02)00084-1

Paul, W. L., \& Taylor, P. A. (2008). A comparison of occupant comfort and satisfaction between a green building and a conventional building. Building and Environment, 43(11), 1858-1870. doi:http://dx.doi.org/10.1016/j.buildenv.2007. 11.006

Pei, Z., Lin, B., Liu, Y., \& Zhu, Y. (2015). Comparative study on the indoor environment 
quality of green office buildings in China with a long-term field measurement and investigation. Building and Environment, 84, 80-88. doi:10.1016/j.buildenv.2014.10.015

Pejtersen, J., Allermann, L., Kristensen, T. S., \& Poulsen, O. M. (2006). Indoor climate, psychosocial work environment and symptoms in open-plan offices. Indoor Air, 16(5), 392-401. doi:10.1111/j.16000668.2006.00444.x

Pellerin, N., \& Candas, V. (2003). Combined effects of temperature and noise on human discomfort. Physiology \& Behavior, 78(1), 99-106.

Quang, T. N., He, C., Knibbs, L. D., de Dear, R., \& Morawska, L. (2014). Co-optimisation of indoor environmental quality and energy consumption within urban office buildings. Energy and Buildings, 85, 225-234. doi:http://dx.doi.org/10.1016/j.enbuild.2014.0 9.021

Ravindu, S., Rameezdeen, R., Zuo, J., Zhou, Z., \& Chandratilake, R. (2015). Indoor environment quality of green buildings: Case study of an LEED platinum certified factory in a warm humid tropical climate. Building and Environment, 84, 105-113. doi:10.1016/j.buildenv.2014.11.001

Rea, M. S. (2000). The IESNA lighting handbook: reference \& application.

Robinson, B., \& Smith, J. (2012). Overview of Green Building and Associated Legal Issues. Natural Resources \& Environment, 26(4), 13 17.

Rossing, T. (2007). Introduction to acoustics Springer Handbook of Acoustics (pp. 1-6): Springer.

Schellen, L., Loomans, M., de Wit, M., \& van Marken Lichtenbelt, W. (2013). The influence of different cooling techniques and gender on thermal perception. Building Research \& Information, 41(3), 330-341. doi:10.1080/09613218.2013.772002

U.S Environmental Protection Agency. (2015). Indoor Air Quality.

US Green Building Council. (2016). USGBC. Retrieved from http://www.usgbc.org/articles/grid

Veitch, J. A., \& Newsham, G. R. (2000). Preferred luminous conditions in open-plan offices: research and practice recommendations. International Journal of Lighting Research and Technology, 32(4), 199-212. doi:10.1177/096032710003200404

Vischer, J. (2008). Towards an Environmental Psychology of Workspace: How People are Affected by Environments for Work.
Architectural Science Review, 51(2), 97-108. doi:10.3763/asre.2008.5114

Wang, Z. (2006). A field study of the thermal comfort in residential buildings in Harbin. Building and Environment, 41(8), 1034-1039. doi:http://dx.doi.org/10.1016/j.buildenv.2005. 04.020

Wilkins, A., Nimmo-Smith, I., Slater, A., \& Bedocs, L. (1989). Fluorescent lighting, headaches and eyestrain. Lighting Research and Technology, 21(1), 11-18.

Wong, L., Mui, K., \& Hui, P. (2008). A multivariate-logistic model for acceptance of indoor environmental quality (IEQ) in offices. Building and Environment, 43(1), 1-6. doi:dx.doi.org/10.1016/j.buildenv.2007.01.00 1

Woo, J. (2014). A systematic post-occupancy evaluation in green-rated high-rise office buildings Architectural Research through to Practice: 48th International Conference of the Architectural Science Association. Genova.

Woo, J. H. (2010). Towards sustainable workplaces: Effects of indoor environmental quality on occupant comfort and work performance. (Doctor of Philosophy), The University of New South Wales, The University of New South Wales.

Wyon, D. P. (2004). The effects of indoor air quality on performance and productivity. Indoor Air, 14, 92-101. doi:10.1111/j.16000668.2004.00278.x

Zimring, C. M., \& Reizenstein, J. E. (1980). Postoccupancy evaluation an overview. Environment and Behavior, 12(4), 429-450. 
